\title{
Energy valuation of urban waste: Vega de Granada case study
}

\author{
J. M. Fernández ${ }^{1}$, M. Zamorano ${ }^{2}$, A. L. Grindlay ${ }^{3}$ \\ $\&$ M. I. Rodríguez ${ }^{3}$ \\ ${ }^{1}$ University of Granada, Spain \\ ${ }^{2}$ Department of Civil Engineering, University of Granada, Spain \\ ${ }^{3}$ Department of Urban and Regional Planning, \\ University of Granada, Spain
}

\begin{abstract}
The EC Directive regarding Municipal Solid Waste (MSW) stipulates that member states should prioritize effective measures for the treatment of residues with a view to developing different forms of valorization, among these energetic. Consequently there is a need to implement management technologies which provide a variety of complementary solutions to recycling and with the aim of avoiding elimination through incineration and landfill.

Different technologies are available for energetic valorization of residues including bio-methanization, pyrolysis, gasification, etc. Each method can be adapted to suit social, ambient, territorial and economic variables. This study provides a cost analysis for 13 municipalities in the province of Granada, Spain, ranging in populations of 300 to 21,500, forming part of a total 93,300 inhabitants, producing 45,000 tons pa of MSW.

Having analyzed bio-methanization, production of Solid Recoverable Fuels (SRF) and gasification, the conclusion is that the introduction of these methods would generate a levy, (council tax) payable by ratepayers/property holders, of $23.29 € / t$, in the case of gasification and 35.96€/t for SRF production technology. These costs compare favourably to the actual incineration and landfill methods used in this area (circa 42€/t) and would produce net financial and environmental benefits in management costs, reduction in the consumption of fossil fuels and reduction of MSW sent to landfill.

Keywords: municipal solid waste, waste to energy, mass and energy balance, mechanical biological treatment, landfill, anaerobic digestion, solid recovered fuel, gasification, tax.
\end{abstract}




\section{Introduction}

In Europe in recent years, volumes of MSW have grown steadily reaching 245 million tons in 2012 (492 kg/person pa). Spain follows this tendency, producing $463 \mathrm{~kg} / \mathrm{p}$ pa of which $63 \%$ is sent to landfill sites [1].

With reference to 1995 levels, the EC Council Directive 1999/31 April 26 on "The Landfill of Waste" targeted member states to reduce biodegradable waste deposits to $50 \%$ by 2013 and to $35 \%$ by 2016 . Also, the EC Directive 2008/98 on MSW, outlines sustainable development plans for urban waste management within the EU [2].

Additionally, it established that the management of residues forms part of a legislative and political programme to transform the EU into a "recycling-is-apriority" society. This dictates that, where economically viable, MSW should always be collected separately, before undergoing further processes of valorization, to provide a better result for the environment.

The EU law corresponds to the Spanish legislative law 22/2011 July 28, on MSW and Land Contamination. The objectives for 2020 mirror the European Directive and promote the benefits for the correct handling of MSW; prevention of greenhouse gasses, reduction of contaminants, savings in energy and natural resources, creating employment, generating economic opportunities and developing environment-friendly technologies [1].

Different technologies can be used efficiently to unlock the important quantity of energy available from urban waste. Their Higher Calorific Value (HCV) is between 18-20 GJ/t and their Lower Calorific Value (LCV) 8-12 GJ/t. The LCV corresponds to $42 \%$ of the combustible value of bituminous carbon (coal) $23.9 \mathrm{GJ} / \mathrm{t}$. Although this may demonstrate that material recovery is uneconomical, it is possible to make an energetic valorization from waste fractions with consequent economic and environmental benefits [3].

Recent years have seen the proliferation of new technologies which employ a low quantity of oxygen in the conversion process, such as pyrolysis and gasification. Both of these technologies improve efficiency and reduce greenhouse gas emissions $[4,5]$.

Pyrolysis is one of the fastest developing technologies in use today for MSW management with satisfactory results from the UK, Turkey and Japan [6]. It is considered as a suitable alternative to conventional methods such as; incineration, landfill, aerobic and anaerobic digestion, open-air burning and composting [7]. Some conventional methods are unsustainable due to their high cost, low efficiency and a long term environmental threat from the high level of greenhouse gas emissions [8].

First generation biofuels from crops; such as ethanol from corn or biodiesel from soya, had a negative response on both social and environmental levels [9].

Second and third generation biofuels from biomass residues are subject to numerous investigations by those looking to lower emissions and reliance on fossil fuels [10].

However, many challenges need to be overcome to enable their production and future commercialization, as well as political and regulatory purposes [11]. 
Modern technologies are an alternative for converting energy from heterogeneity MSW byproducts with a proven energetic value [12, 13].

The combination of heat and energy production systems such as in incineration plants and using SRF as a raw material, offers significant environmental benefits as shown by $(0.04-0.14 \mathrm{Kg} / \mathrm{MJ})$ when compared to the actual $\mathrm{Kg} / \mathrm{MJ}$ values for incineration of fossil fuels [14, 15].

Energetic valorization is already present amongst the leading industrialized nations with Europe considered leaders in this field. However, specific areas in Asia will undergo development $[16,17]$.

In Europe; Germany, Holland, Belgium, Austria Switzerland and Denmark have made most progress in energetic valorization from MSW. Spain, with waste-to-landfill elimination levels of $63 \%$, is above the European average, estimated at $33 \%$ [1].

However, with only an estimated $9 \%$ of those residues classified for energetic valorization it is well below the European average of $26 \%$ [1].

The purpose of this study, in line with the objectives set by the EU and with a view to reducing the quantity of waste sent to landfill, is to make a cost analysis comparing various technologies of energetic valorization for urban waste. The study was conducted in an area of the province of Granada, Spain, and compares distinct treatment alternatives namely: bio-methanization, SRF production and gasification. This preliminary analysis needs to be continued to study in equal measure additional aspects, namely environmental and social, related to the implementation of these systems.

\section{Materials and methods}

\subsection{Study location}

This study refers to a group of towns and villages located in the Vega de Granada, Spain (Fig. 1). The combined population is 93,300 which generate $45,000 \mathrm{t} / \mathrm{yr}$. of residual waste made up of various materials (Fig. 2).
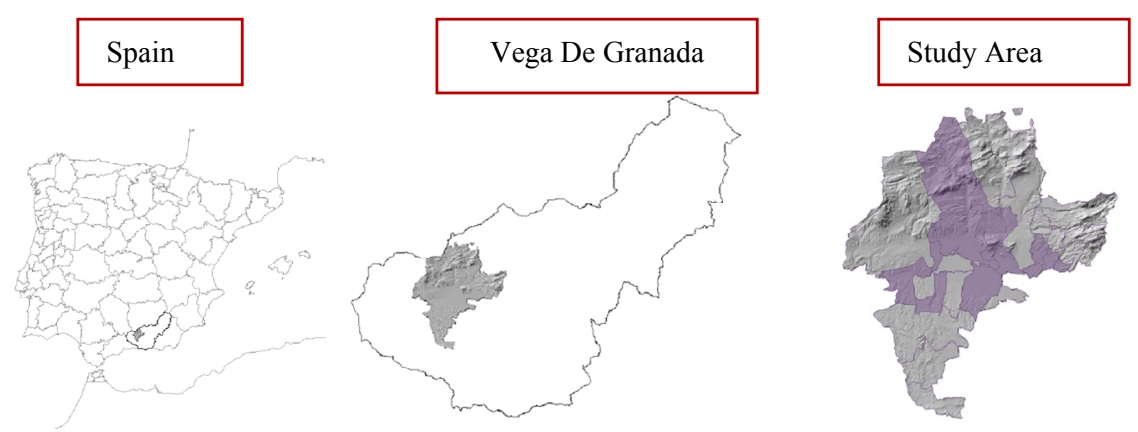

Figure 1: Study location. 


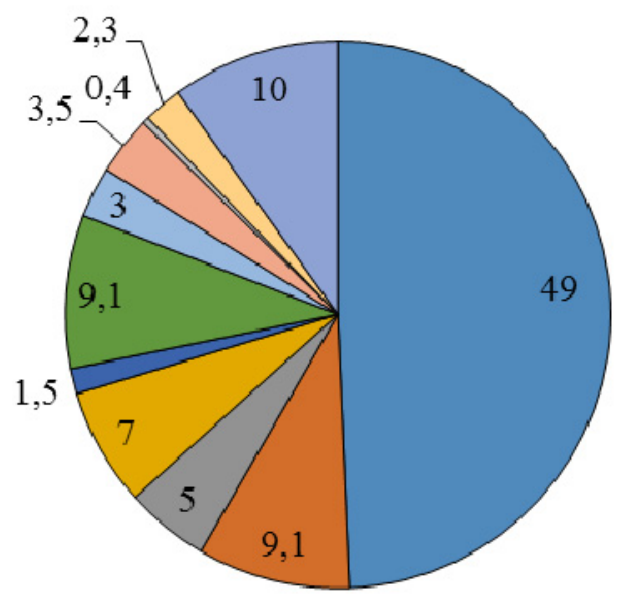

$\square$ Organic Matter

$\square$ Paper-Paperboard

$\square$ Glass

$\square \mathrm{PET}$

$\square \mathrm{HDPE}$

$\square$ Film

$\square$ Plastic mix

$\square$ Ferrous

$\square$ Non-ferrics

Bricks

Figure 2: Urban waste breakdown [18].

The mechanical-biological treatment (MBT) plant for this area handles the recovery of recyclables (metals, packaging, paper/cardboard and glass) and produces bio-stabilized material from the aerobic decomposition of the fermentable waste fraction. This plant does not have technology at their disposal, to place an energetic valorization on MSW. Therefore, more than $60 \%$ of the annual waste intake ends up in landfill.

\subsection{Analysis of energetic valorization technologies}

Various methods are available to carry out an energetic valorization of MSW. In this study different technologies have been researched based on pre-treatment at a mechanical-biological plant (MBT), going through an onsite valorization facility before being sent to landfill, for further treatment.

The proposed solutions for this study are outlined in table 1. All the solutions except option $\mathrm{D}$ use a mechanical biological pre-treatment plant for urban waste and include: i) mechanical recovery of recyclables (paper, metal etc.) and ii) biological treatment under anaerobic and/or aerobic conditions to reduce and stabilize the biodegradable organic fraction [19].

The flow-chart diagrams that follow demonstrate the proposed alternatives. For the purpose of this study the estimate for MSW treatable volumes are 45,000 $\mathrm{t} / \mathrm{yr}$ and mechanical recovery rate $9 \%[18]$.

From the mechanical process, the resultant reject volumes correspond to $39.52 \%$. Added to this figure is the rejected volume from the biological treatment process. The efficiency and performance coefficient of the energetic valorization process has been established in accordance with estimates provided by companies who operate with these technologies.

Table 2 shows the mass balance of recyclable material, biodegradable material and the material and energetic valorization for each alternative. 
Table 1: Alternative treatment definitions used in this study.

\begin{tabular}{|c|c|c|c|c|}
\hline Alternative & Definition & $\begin{array}{c}\text { Pre-treatment } \\
\text { before } \\
\text { valorization }\end{array}$ & $\begin{array}{c}\text { Technology used } \\
\text { for energetic } \\
\text { valorization }\end{array}$ & Elimination \\
\hline $\begin{array}{c}\text { Alternative } \\
0\end{array}$ & $\begin{array}{c}\text { MBT plant, rejects to } \\
\text { landfill, without } \\
\text { energetic recovery }\end{array}$ & $\begin{array}{c}\text { Mechanical- } \\
\text { biological }\end{array}$ & None & Landfill \\
\hline $\begin{array}{c}\text { Alternative } \\
\text { A }\end{array}$ & $\begin{array}{c}\text { MBT plant, rejects to } \\
\text { landfill, with energetic } \\
\text { recovery }\end{array}$ & $\begin{array}{c}\text { Mechanical- } \\
\text { biological }\end{array}$ & None & $\begin{array}{c}\text { Landfill or } \\
\text { degasification }\end{array}$ \\
\hline $\begin{array}{c}\text { Alternative } \\
\text { B }\end{array}$ & $\begin{array}{c}\text { MBT plant landfill plus } \\
\text { anaerobic digestion of } \\
\text { the organic fraction } \\
\text { with energy recovery }\end{array}$ & $\begin{array}{c}\text { Mechanical- } \\
\text { biological }\end{array}$ & Bio-methanization & $\begin{array}{c}\text { Landfill or } \\
\text { degasification }\end{array}$ \\
\hline $\begin{array}{c}\text { Alternative } \\
\text { C }\end{array}$ & $\begin{array}{c}\text { MBT plant and SRF } \\
\text { production, rejects to } \\
\text { landfill, with energetic } \\
\text { recovery }\end{array}$ & $\begin{array}{c}\text { Mechanical- } \\
\text { biological }\end{array}$ & SRF & $\begin{array}{c}\text { Landfill or } \\
\text { degasification }\end{array}$ \\
\hline $\begin{array}{c}\text { Alternative } \\
\text { D }\end{array}$ & $\begin{array}{c}\text { Mechanical treatment } \\
\text { and gasification plant }\end{array}$ & Mechanical & Gasification & Ash to landfill \\
\hline
\end{tabular}

Table 2: Mass balance and energetic valorization of by-products.

\begin{tabular}{|c|c|c|c|c|c|}
\hline Alternative & Recyclables & Biodegradables & Bio-stabilized & Rejects & By-products \\
\hline Alternative 0 & 9 & 51.48 & 20.60 & 53.52 & -- \\
\hline Alternative A & 9 & 51.48 & 20.60 & 53.52 & $0.12 \mathrm{MWh} / \mathrm{t}$ \\
\hline Alternative B & 9 & 51.48 & 9.71 & 51.23 & $0.29 \mathrm{MWh} / \mathrm{t}$ \\
\hline Alternative C & 9 & 51.48 & 20.60 & 29.44 & $\begin{array}{c}24.08 \% \mathrm{SRF} \\
0.06 \mathrm{MWh} / \mathrm{t}\end{array}$ \\
\hline Alternative D & 8 & 48 & -- & 10 & $\begin{array}{c}0.21 \mathrm{MWh} / \mathrm{t} \\
\text { Calorific }\end{array}$ \\
\hline
\end{tabular}

\subsubsection{Alternative 0}

This option corresponds to actual urban waste treatment method used in the Vega de Granada. Energetic valorization is not employed.

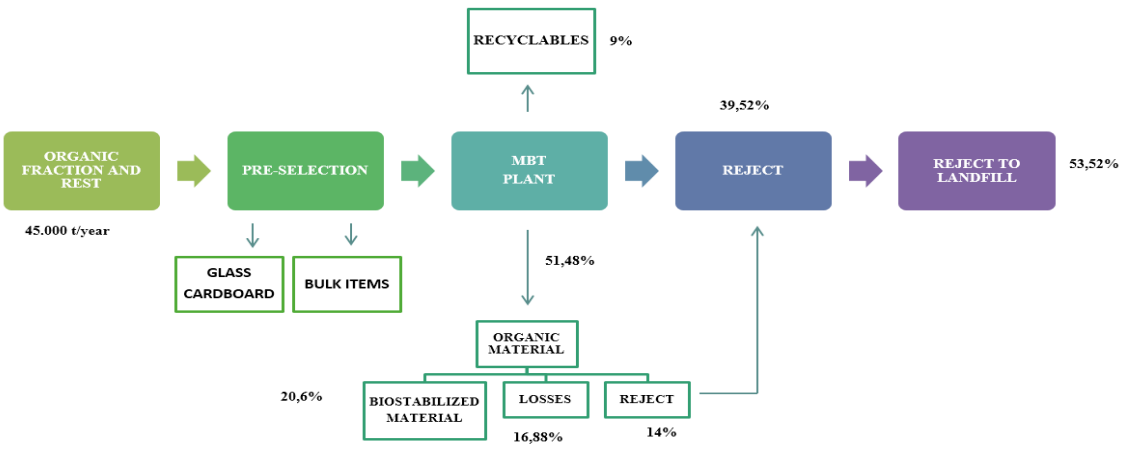

Figure 3: Mass balance in MBT and landfill plant without energy recovery. 


\subsubsection{Alternative A}

As in "Alternative 0 " with energy recovery from rejects prior to landfill.

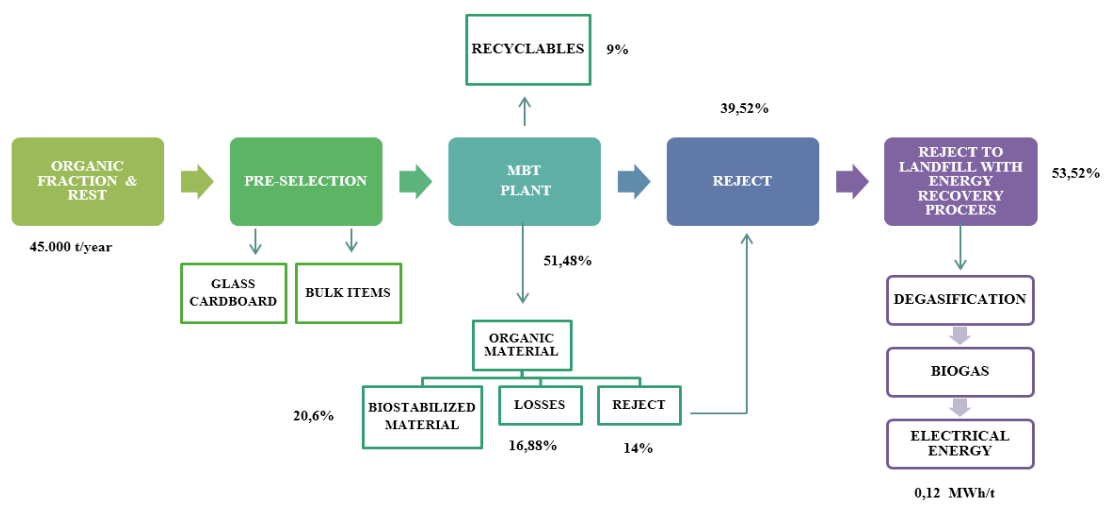

Figure 4: Mass balance in MBT with energy recovery from reject.

\subsubsection{Alternative B}

This option incorporates a bio-methanization plant enabling the site to obtain electrical energy from the decomposition of organic matter through anaerobic digestion and thermophile processes. With the method, from $51.48 \%$ of the biodegradable material destined to anaerobic digestion, $0.18 \mathrm{MWh} / \mathrm{t}$ of electrical energy can be produced. Through developing this anaerobic phase prior to the aerobic digestion of biodegradables, the percentage of bio-stabilized material is reduced, in this case, to $9.71 \%$ approx.

From the rejected percentage destined to landfill, $51.23 \%$, exists the option of degasification which in turn would produce a further $0.11 \mathrm{MWh} / \mathrm{t}$.

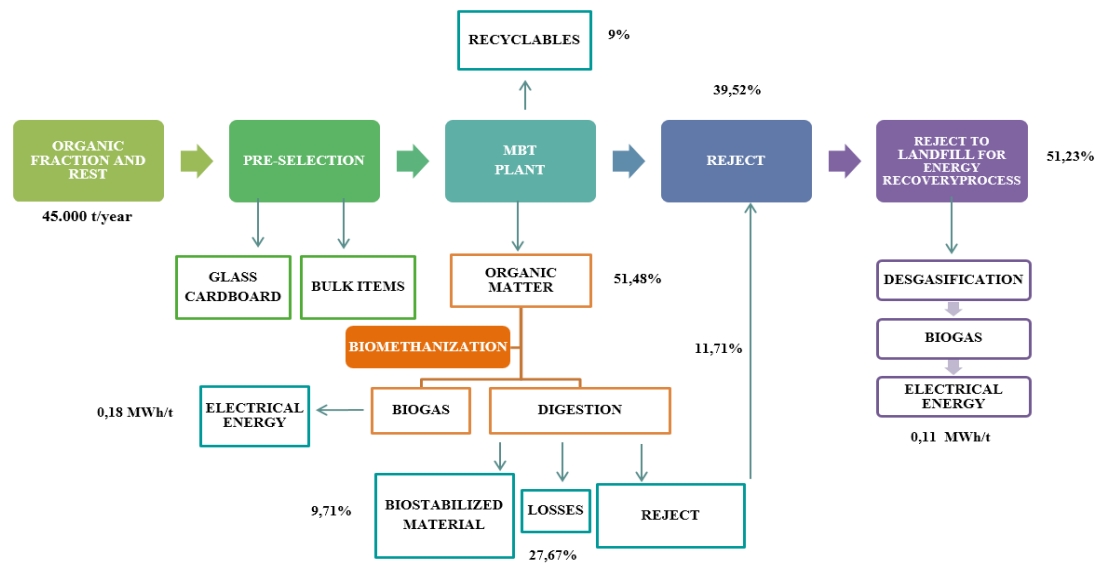

Figure 5: Mass balance in MBT plant, anaerobic of digestion with landfill and energy recovery. 


\subsubsection{Alternative C}

This option incorporates a production plant for SRF, able to process the percentage of rejected waste; such as the $52.3 \%$ from a mechanical-biological plant as described in Alternative A. From the SRF plant $24.08 \%$ of reject-waste could be converted into an energetically valued biofuel. An SRF plant has a reject rate of about $29.44 \%$ from its initial product intake. If this option was selected, $0.06 \mathrm{MWh} / \mathrm{t}$ of energy could be recovered through degasification from the rejected materials destined for landfill.

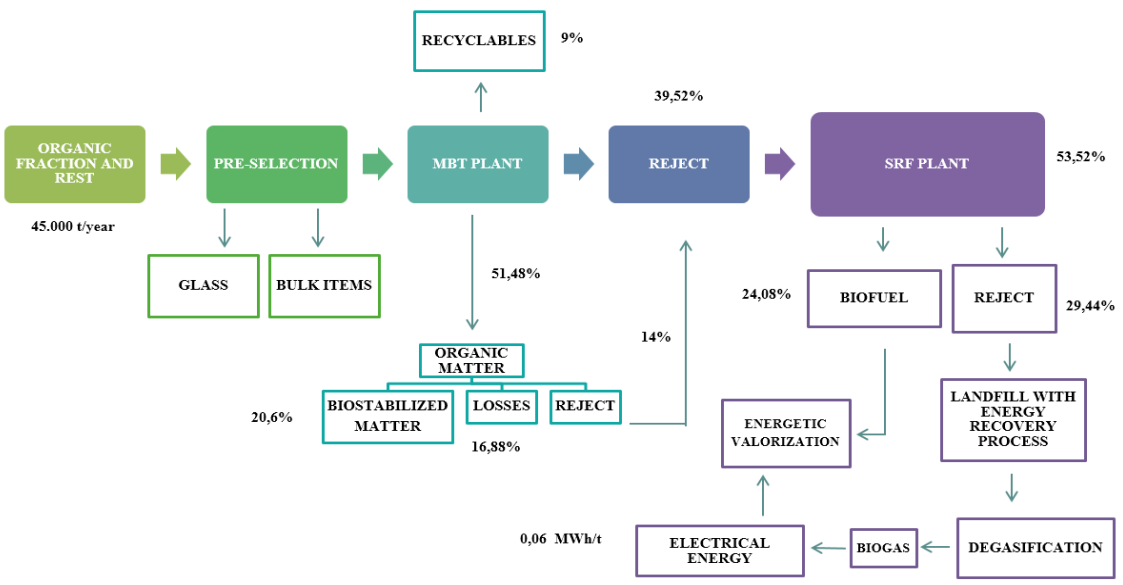

Figure 6: Mass balance at MBT/SRF production plant with energy recovery.

\subsubsection{Alternative D}

The last option in this study is a gasification plant. Here the energetic valorization of MSW is calculated from the electrical energy generated by gasification reactors.

The MSW is treated mechanically. Then the biodegradable fraction is converted with driers, powered by the thermal energy released during the process. The gasifiable fraction (without chlorinated materials) is introduced into the reactor to generate $0.21 \mathrm{MWh} / \mathrm{t}$ of electrical energy.

Materials invalid for gasification (chlorinates) comprise of about $20 \%$ of the intake and have a high material value.

The reject rate, around $10 \%$, from this alternative consists mainly of ash which will be sent to landfill.

\subsection{Methodology and economic analysis}

The levy (canon) payable by ratepayers/property holders towards the running costs of MSW treatment and elimination, is the difference between overhead, expenditure and generated income. The calculation criteria used for each alternative is detailled as follows. 


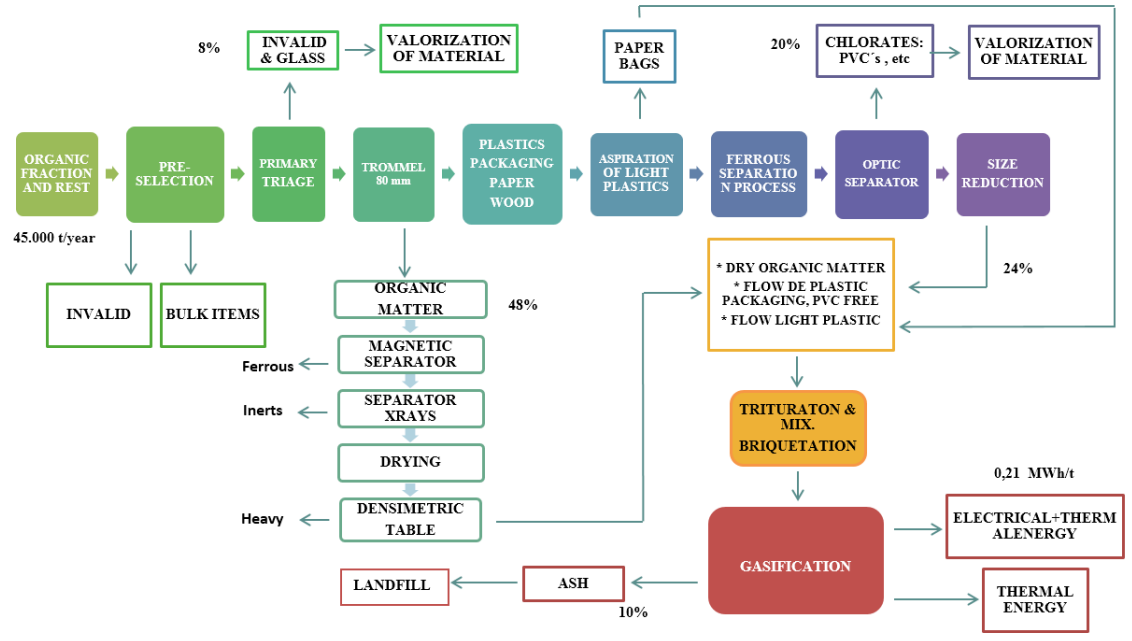

Figure 7: Mechanical treatment with gasification plant.

Table 3: Associated costs for treatment plant and elimination of urban waste.

\begin{tabular}{|rl|}
\hline 1. & Investment and amortization \\
\hline 2. & Cost of human resources \\
\hline 3. & Operating costs \\
\hline 4. & Levy (Canon) allocation \\
\hline 5. & Central services (and/or common) \\
\hline
\end{tabular}

\subsubsection{Cost calculation}

To calculate the levy the study criteria as listed in table 3 was used.

\section{Investment and amortization}

Investment costs for each plant are based on type and use. Total investment costs will vary subject to land prices, civil engineering and construction work, machinery etc. Amortization scheduling and interest rates (estimated) are also included.

\section{Human resources costs}

Staffing requirements and contract types will be subject to specific treatment areas within the plant and individual operator function.

The MSW potential or actual tonnage intake a will determine the number of full-time, part-time and/or temporary workers needed.

The annual cost of each full-time employee is calculated subject to category, shift-work and number of posts filled per position.

The annual cost calculation for part-time and temporary personnel is based on MSW volume intake, the number of workers required per hour for each function and the established remuneration for the distinctive categories/salary levels. 
Therefore, personnel costs will vary year on year subject to the volumes of MSW treated and in accordance with the contractual conditions as outlined above.

\section{Operating costs}

Fixed and variable operating costs for each alternative are calculated in correlation with the tonnage of waste to be treated.

Fixed costs, vehicle and site insurances, fixed supply lines, repair and maintence costs (expressed as a percentage on balance sheet).

These costs can be directly applied to one operation or distributed between various, thus the need to apply assignment criteria to them.

Variable costs differ subject to individual criteria in relation to the general parameters of each instalation and fluctuate subject to the plant capacity, waste volumes etc.

\section{Council levy allocation}

The criteria used to calculate the council levies are based on cost estimates per plant as detailed previously.

Logically the total costs, fixed or variable, associated with a specific activity can be allocated directly and integrally. Each cost-centre will apply a percentage levy based on annual tonnage and the composition of treated waste plus the investment in "fit for purpose" plant and machinery.

\section{Costings for central and common services}

These costs are considered as: purchase of land for site location, buildings and amenities, roads, car parks, etc. plus civil engineering and other construction projects such as offices, changing rooms, staff canteen, environmental teaching facility, weighbridge etc.

The above costs are not subject to activities directly associated with the levy but form part of the initial investment infrastructure required to carry out all operations associated with the MSW management and concession.

Included in this cost area is general maintenance, admin. etc., management company set up costs, environmental awareness campaigns, rates, taxes.

Table 4 shows the coefficent values used to calculate the cost of the different alternatives (NB Table 7 shows a cost breakdown in $€ / t$ for each alternative).

\subsubsection{Income calculations}

Treatment and valorization of waste can produce income through the sale of byproducts and energy production. What factors determine this income is detailed as follows.

\section{Sales of byproducts}

Income estimates from byproduct sales per ton are based on price and/or compensation applicable to each of the Integrated Managent Systems studied. Producers place at the disposal of their clients tariffs for energy and material as required.

Potential income will depend on how the percentages of recoverable materials per site are classified; biostabilized material, SRF, bio-methanization energy production and energetic production through gasification. 
Table 4: Cost calculation coefficients.

\begin{tabular}{|c|c|c|c|c|c|c|}
\hline Description & \begin{tabular}{|c|} 
Alternative \\
0
\end{tabular} & $\begin{array}{c}\text { Alternative } \\
\text { A }\end{array}$ & $\begin{array}{c}\text { Alternative } \\
\text { B }\end{array}$ & $\begin{array}{c}\text { Alternative } \\
\text { C }\end{array}$ & $\begin{array}{l}\text { Alternative } \\
\text { D }\end{array}$ & References \\
\hline $\begin{array}{l}\text { Amortization plant } \\
\text { machinery (yrs) }\end{array}$ & 20 & 20 & 20 & 20 & 20 & \multirow{14}{*}[20-25]{} \\
\hline $\begin{array}{l}\text { Machinery } \\
\text { exploitation and } \\
\text { amortization (yrs) }\end{array}$ & 20 & 20 & 20 & 20 & 20 & \\
\hline $\begin{array}{l}\text { Civil eng./works } \\
\text { amortization (yrs) }\end{array}$ & 20 & 20 & 20 & 20 & 20 & \\
\hline Personnel & 17 & 17 & 17 & 16 & 12 & \\
\hline $\begin{array}{l}\text { Plant machine } \\
\text { maintenance/repair } \\
\text { (\%/investment) }\end{array}$ & 10.30 & 10.25 & 6.93 & 9.85 & 11.81 & \\
\hline $\begin{array}{l}\text { Explotation machine } \\
\text { maintenance/repair } \\
\text { (\%/investment) }\end{array}$ & 4 & 3.78 & 3.51 & 3.60 & 4.91 & \\
\hline $\begin{array}{l}\text { Power (\% } \\
\text { s/inversion) }\end{array}$ & 2.1 & 0.20 & 1.90 & 2.46 & 3.55 & \\
\hline $\begin{array}{l}\text { Water and other } \\
\text { materials } \\
\text { (\%/investment) }\end{array}$ & 0.7 & 0.65 & 0.78 & 0.69 & 1.01 & \\
\hline $\begin{array}{l}\text { Insurances } \\
\text { (\%/investment) }\end{array}$ & 0.2 & 0.18 & 0.17 & 0.17 & 0.23 & \\
\hline $\begin{array}{l}\text { Consultants and } \\
\text { external technical } \\
\text { support }(€)\end{array}$ & 60,000 & 60,000 & 60,000 & 60,000 & 60,000 & \\
\hline $\begin{array}{l}\text { Other contingencies } \\
(\%)\end{array}$ & 1.37 & 1.31 & 3.93 & 1 & 3.12 & \\
\hline Financial costs $(5 \%)$ & 5 & 5 & 5 & 5 & 5 & \\
\hline $\begin{array}{l}\text { General overhead and } \\
\text { industrial profit } \\
(16 \%)\end{array}$ & 16 & 16 & 16 & 16 & 16 & \\
\hline $\begin{array}{l}\text { Value added tax VAT } \\
(10 \%)\end{array}$ & 10 & 10 & 10 & 10 & 10 & \\
\hline
\end{tabular}

Given the uncertainty surrounding applicable prices and which byproducts can be produced, for the purpose of this study it is estimated that $80 \%$ of byproducts will generate income.

Sales prices are subject to market fluctuations. Long term future rates are impossible to predict. Conservative sales prices have been used for SRF, biostabilized material and material recovered from phase 1 of the mechanical treatment process.

\section{Electric energy from anaerobic digestion and gasification}

In these cases consideration must be given to price variations set by the State Energy regualator (Spain). Values are based on average prices for renewable 
energy sources (2013-2014). Table 6 shows by-product energy yields of energetic valorization for each alternative.

\section{Energy produced through landfill degasification}

For the alternatives with landfill options, this study includes income derived from electrical energy produced from bio-gas collection (as outlined above) and stipulated in the Spanish law RD 1481/2001 December 27, from the EC Directive 1999/31, which regulates landfill and biogas production.

Biogas production depends mainly on local climatological factors, composition of waste fractions and time related degradabilty.

This paper contemplates landfill explotation for an average year during the active lifetime of the plant, to obtain a value for energetic production.

Table 5: By-product selling prices.

\begin{tabular}{|c|c|c|c|c|}
\hline & Valorizable - Output & By-product type & Price & References \\
\hline \multirow{4}{*}{ Alternative 0} & \multirow{3}{*}{ Recoverable Materials } & Light packaging & $200 € / \mathrm{t}$ & \multirow{3}{*}{ [26] } \\
\hline & & Paper/cardboard & $30 € / \mathrm{t}$ & \\
\hline & & Glass & $45 € / t$ & \\
\hline & \multicolumn{2}{|c|}{ Biostabilized Material } & $10 € / \mathrm{t}$ & [27] \\
\hline \multirow{5}{*}{ Alternative A } & \multirow{3}{*}{ Recoverable Materials } & Light packaging & $200 € / t$ & \multirow{3}{*}{ [26] } \\
\hline & & Paper/cardboard & $30 € / t$ & \\
\hline & & Glass & $45 € / t$ & \\
\hline & \multicolumn{2}{|c|}{ Biostabilized Material } & $10 € / \mathrm{t}$ & [27] \\
\hline & Electrical Energy from Landfill & Biogas & $0.055 € / \mathrm{KWh}$ & [28] \\
\hline \multirow{6}{*}{ Alternative B } & \multirow{3}{*}{ Recoverable Materials } & Light packaging & $200 € / \mathrm{t}$ & \multirow{3}{*}{ [26] } \\
\hline & & Paper/cardboard & $30 € / t$ & \\
\hline & & Glass & $45 € / \mathrm{t}$ & \\
\hline & \multicolumn{2}{|c|}{ Biostabilized Material } & $10 € / \mathrm{t}$ & [27] \\
\hline & Electrical Energy from Process & Biogas & $0.055 € / \mathrm{KWh}$ & {$[28]$} \\
\hline & Electrical Energy from Landfill & Biogas & $0.055 € / \mathrm{KWh}$ & [28] \\
\hline \multirow{6}{*}{ Alternative $\mathrm{C}$} & \multirow{3}{*}{ Recoverable Materials } & Light packaging & $200 € / t$ & \multirow{3}{*}{ [28] } \\
\hline & & Paper/cardboard & $30 € / t$ & \\
\hline & & Glass & $45 € / t$ & \\
\hline & \multicolumn{2}{|c|}{ Biostabilized Material } & $10 € / t$ & [27] \\
\hline & Processed Materials & SRF & $25 € / t$ & [29] \\
\hline & Electrical Energy from Landfill & Biogas & $0.055 € / \mathrm{t}$ & [28] \\
\hline \multirow{3}{*}{ Alternative D } & \multirow{2}{*}{ Recoverable Materials } & Chlorinated Plastic & $130 € / \mathrm{t}$ & \multirow{2}{*}{$\begin{array}{l}{[25]} \\
{[26]}\end{array}$} \\
\hline & & Glass & $45 € / t$ & \\
\hline & Electrical Energy from Process & Syngas & $0.055 € / \mathrm{kWh}$ & [25] \\
\hline
\end{tabular}


Table 6: By-products or outcome from energetic valorization and yields.

\begin{tabular}{|c|c|c|c|c|c|}
\hline & Phase & $\begin{array}{c}\text { By-product } \\
\text { Energetic } \\
\text { Valorization }\end{array}$ & Yield & $\begin{array}{l}\text { Operative } \\
\text { hrs/yr }\end{array}$ & References \\
\hline $\begin{array}{c}\text { Alternative } \\
0\end{array}$ & Plant Explotation & - & - & 1820 & [20] \\
\hline \multirow[b]{2}{*}{$\begin{array}{c}\text { Alternative } \\
\text { A }\end{array}$} & Plant Explotation & - & - & 1820 & [20] \\
\hline & Anaerobic Digestion in Landfill & Biogas & $\begin{array}{c}80 \mathrm{Nm}^{3} / \mathrm{t} \\
40 \%\end{array}$ & 8760 & [30] \\
\hline \multirow{3}{*}{$\begin{array}{l}\text { Alternative } \\
\text { B }\end{array}$} & Plant Explotation & - & - & 1820 & [20] \\
\hline & $\begin{array}{l}\text { Anaerobic Digestion in Bio- } \\
\text { methanization }\end{array}$ & Biogas & $\begin{array}{c}340 \\
\mathrm{kWh} / \mathrm{t}\end{array}$ & 8760 & [31] \\
\hline & Anaerobic Digestion in Landfill & Biogas & $\begin{array}{c}80 \mathrm{Nm}^{3} / \mathrm{t} \\
40 \%\end{array}$ & 8760 & [30] \\
\hline \multirow{3}{*}{$\begin{array}{l}\text { Alternative } \\
\text { C }\end{array}$} & Plant Explotation & - & - & 1820 & {$[20]$} \\
\hline & Production & SRF & $45 \%$ & 1820 & {$[24]$} \\
\hline & Anaerobic Digestion in Landfill & Biogas & $\begin{array}{c}110 \\
\mathrm{Nm}^{3} / \mathrm{t} \\
55 \%\end{array}$ & 8760 & {$[30]$} \\
\hline \multirow{2}{*}{$\begin{array}{l}\text { Alternative } \\
\text { D }\end{array}$} & Plant Explotation & - & - & 6200 & [25] \\
\hline & Gasification & Syngas & $80 \%$ & 6200 & {$[25]$} \\
\hline
\end{tabular}

\section{Results}

Based on the criteria indicated above and in the corresponding flow charts, tables 7 and 8 collate the costs for each alternative.

In table 9 the balance shows the council levy per ton applicable by property holders/ratepayers for the removal and treatment of MSW. It represents the shortfall between investment, operating costs and amortization and income derived from sales of byproducts.

Note that option D which corresponds to a mechanical treatment and gasification plant requires the least contribution $23.29 € / \mathrm{t}$.

In Vega de Granada, the introduction of this technology would produce savings for MSW management of $18 € / \mathrm{t}$ compared to the actual situation.

Valorization of MSW through gasification has been used for several years. By contrasting and comparing actual results from countries that have successfully implemented this technology along with the development of modern reactors, gas purification systems etc., infers that this technology is the most appropriate for this area.

The Vega de Granada plant currently employs Alternative 0 technology which in fact is the most expensive option.

\section{Conclusion}

The research and study of various alternatives concludes that, the energetic valorization from the "rest" fraction offers important economic benefits as opposed to the actual method used which relies too heavily on landfill. 
Table 7: Cost by alternative.

\begin{tabular}{|l|c|c|c|c|c|}
\hline & $\begin{array}{c}\text { Alternative } \\
0(€ / \mathrm{t} \text { yr })\end{array}$ & $\begin{array}{c}\text { Alternative } \\
\mathrm{A}(€ / \mathrm{t} \text { yr })\end{array}$ & $\begin{array}{c}\text { Alternative } \\
\mathrm{B}(€ / \mathrm{t} \mathrm{yr})\end{array}$ & $\begin{array}{c}\text { Alternative } \\
\mathrm{C}(€ / \mathrm{t} \text { yr })\end{array}$ & $\begin{array}{c}\text { Alternative } \\
\mathrm{D}(€ / \mathrm{t} \mathrm{yr})\end{array}$ \\
\hline $\begin{array}{l}\text { Amortization plant } \\
\text { machinery }\end{array}$ & 9.79 & 10.26 & 13.10 & 11.84 & 13.27 \\
\hline $\begin{array}{l}\text { Machinery } \\
\text { exploitation and } \\
\text { amortization }\end{array}$ & 0.67 & 0.67 & 0.66 & 0.88 & 1.76 \\
\hline $\begin{array}{l}\text { Civil eng./works } \\
\text { amortization }\end{array}$ & 7.84 & 9.40 & 9.40 & 10.12 & 7.52 \\
\hline Personnel & 14.15 & 14.15 & 14.48 & 13.35 & 10.37 \\
\hline $\begin{array}{l}\text { Plant machine } \\
\text { maintenance/repair }\end{array}$ & 5.98 & 6.27 & 4.55 & 6.33 & 7.84 \\
\hline $\begin{array}{l}\text { Explotation machine } \\
\text { maintenance/repair }\end{array}$ & 2.31 & 2.31 & 2.31 & 2.32 & 3.26 \\
\hline Power & 1.22 & 1.22 & 1.25 & 1.58 & 2.36 \\
\hline $\begin{array}{l}\text { Water and other } \\
\text { materials }\end{array}$ & 0.40 & 0.40 & 0.51 & 0.45 & 0.67 \\
\hline Insurances & 0.11 & 0.11 & 0.12 & 0.11 & 0.15 \\
\hline $\begin{array}{l}\text { Consultants and } \\
\text { external technical } \\
\text { support (€) }\end{array}$ & 1.33 & 1.33 & 1.33 & 1.33 & 1.33 \\
\hline Other contingencies & 0.80 & 0.80 & 2.58 & 0.95 & 2.07 \\
\hline Financial costs $(5 \%)$ & 1.02 & 1.02 & 1.16 & 1.14 & 1.35 \\
\hline $\begin{array}{l}\text { General overhead } \\
\text { and industrial profit } \\
(16 \%)\end{array}$ & 7.67 & 7.67 & 8.23 & 8.06 & 8.33 \\
\hline VAT (10\%) & 5.56 & 5.56 & 5.97 & 5.84 & 6.03 \\
\hline Total (€/t) & 58.06 & 61.16 & 65.62 & 64.29 & 66.41 \\
\hline
\end{tabular}

Table 8: Sales income from valorized product for each alternative.

\begin{tabular}{|l|c|c|c|c|c|}
\hline & $\begin{array}{c}\text { Alternative } \\
0(€ / \mathrm{t} \mathrm{yr})\end{array}$ & $\begin{array}{c}\text { Alternative } \\
\mathrm{A}(€ / \mathrm{t} \mathrm{yr})\end{array}$ & $\begin{array}{c}\text { Alternative } \\
\mathrm{B}(€ / \mathrm{t} \mathrm{yr})\end{array}$ & $\begin{array}{c}\text { Alternative } \\
\mathrm{C}(€ / \mathrm{t} \mathrm{yr})\end{array}$ & $\begin{array}{c}\text { Alternative } \\
\mathrm{D}(€ / \mathrm{t} \mathrm{yr})\end{array}$ \\
\hline Recoverable materials & 13.59 & 13.59 & 13.59 & 13.59 & 31.75 \\
\hline Bio-stabilized materials & 2.06 & 2.06 & 0.86 & 2.06 & - \\
\hline Materials from process & - & - & - & 6.02 & - \\
\hline $\begin{array}{l}\text { Electrical energy from } \\
\text { process }\end{array}$ & - & - & 9.63 & - & 11.37 \\
\hline $\begin{array}{l}\text { Electrical energy from } \\
\text { landfill }\end{array}$ & - & 6.41 & 6.13 & 6.66 & - \\
\hline Total $(€ / \mathrm{t})$ & 15.65 & 22.06 & 30.21 & 28.33 & 43.12 \\
\hline
\end{tabular}

Table 9: Final balance of the alternatives (canon).

\begin{tabular}{|c|c|c|c|c|c|}
\hline & $\begin{array}{c}\text { Alternative 0 } \\
(€ / \mathrm{t} \text { yr })\end{array}$ & $\begin{array}{c}\text { Alternative A } \\
(€ / \mathrm{t} \text { yr })\end{array}$ & $\begin{array}{c}\text { Alternative B } \\
(€ / \mathrm{t} \mathrm{yr})\end{array}$ & $\begin{array}{c}\text { Alternative C } \\
(€ / \mathrm{t} \mathrm{yr})\end{array}$ & $\begin{array}{c}\text { Alternative D } \\
(€ / \mathrm{t} \mathrm{yr})\end{array}$ \\
\hline Canon & 42.41 & 39.10 & 35.41 & 35.96 & 23.29 \\
\hline
\end{tabular}


Also implementing these systems secures compliance with the EC 1999/31 Council Directive 26 April 1999 on The Landfill of Waste.

On completion of the economic viability study (energetic valorization systems) it is necessary to undertake a wider study, of important decisionmaking variables and identify the best alternative from social and environmental perspectives.

\section{References}

[1] EUROSTAT, http://ec.europa.eu/eurostat/statistics-explained/index.php/ Municipal_waste_statistics

[2] Ionescu, G., Merler, G., Rada, E. C. \& Ragazzi, M. Integrated valorification system of MSW: Metropolitan area case study. In: Proceedings of 5th international conference on energy and environment, Bucharest, Romania, 2011.

[3] Poulsen, T.G. \& Hansen, J.A. Assessing the impacts of changes in treatment technology on energy and greenhouse gas balances for organic waste and waste water treatment using historical data. Waste Management and Research, 27, pp. 861-870, 2009.

[4] Huang, H. \& Tang, L. Treatment of organic waste using thermal plasma pyrolysis technology. Energy Convers Manage, 48, pp. 1331-1337, 2007.

[5] Arena U. Process and technological aspects of municipal solid waste gasification. A review. Waste Manage, 32, pp. 625-639, 2012.

[6] Caruso, W., Sorenson, D. \& Mossa, A. Alternative energy technologies: Hitech solutions for urban carbon reduction, London: London Borough of Merton Council, 2008.

[7] Serio, A., Kroo, E., Bassilakis, R., Suuberg, E.M. \& Wojtowicz, M. A. A prototype pyrolyzer for solid waste resource recovery in space, Society of Automobile Engineers, 23(2), pp. 435-446, 2001.

[8] Scott, D.S., Piscorz, J., Bergougnou, M.A., Graham, R. \& Overend, R. E. The Role of Temperature in Fast Pyrolysis of Cellulose and Wood. Industrial Engineering Chemical Research, 27(1), pp. 8-11, 1988.

[9] Fargione, J., Hill, J. \& Tilman, D. Land clearing and the biofuel carbon debt. Science, 319, pp. 1235-1238, 2008.

[10] Scharlemann, J.P.W. \& Laurance, W.F. Environmental science: How green are biofuels? Science, 319, pp. 43-44, 2008.

[11] Williams, R.B. Biofuels from Municipal Wastes - Background Discussion Paper. Department of Biological and Agricultural Engineering. University of California, 2007.

[12] Ionescu, G., Marculescu, C. \& Badea, A. Alternative solutions for MSW to energy conversion. U.P.B. Sci Bull, Ser C Electr Eng, 73, pp. 243-254, 2010.

[13] Baggio, P., Baratieri, M., Fioria, L., Grigiante, M., Avi, D. \& Tosi, P. Experimental and modeling analysis of a batch gasification/pyrolysis reactor. Energy Convers Manage, 50, pp. 1426-4635, 2009. 
[14] Finney, K.N., Chen, Q., Sharifi, V.N., Swithenbank, J., Nolan, A \& White, S. Developments to an existing city-wide district energy network: part II analysis of environmental and economic impacts. Energy Convers Manage, 62, pp. 176-184, 2012.

[15] Rada, E.C. \& Andreottola, G. RDF/SRF which perspective for its future in EU. Waste Manage, 32, pp. 1059-1060, 2012.

[16] Suksankraisorn, K., Patumsawad, S., Vallikul, P., Fungtammasan, B. \& Accary, A. Combustion of municipal solid waste and Thai lignite in a fluidized bed. Energy Convers Manage, 45, pp. 947-962, 2004.

[17] Zhiqiang, L., Zhihua, L. \& Xiaolin, L. Status and prospect of the application of municipal solid waste incineration in China. Appl Therm Eng, 26, pp. 1193-1197, 2006.

[18] DIPUTACIÓN DE GRANADA, http://www.dipgra.es/

[19] Bayard, R., de Araújo Morais, J., Ducom, G., Achur, F., Rouez, M. \& Gourdon, R. Assessment of the effectiveness of an industrial unit of mechanical-biological treatment of municipal solid waste. Journal of Hazardous Materials, 175, pp. 23-32, 2009.

[20] Masias Recycling, http://masiasrecycling.com/

[21] FCC, http://www.fcc.es/fccweb/index.html

[22] Cogersa, http://www.cogersa.es/metaspace/portal/14498/14519-inicio

[23] Acciona, http://www.acciona.es/

[24] Complejo Para Tratamiento De Residuos Urbanos De Zaragoza, http://www.zaragozarecicla.org/

[25] Dimasa Grupo, http://www.dimasagrupo.com/

[26] Ecoembes, http://www.ecoembes.com/es

[27] Ministerio de Agricultura, Alimentación y Medio Ambiente (Magrama), http://www.magrama.gob.es/es/

[28] OMIE, http://www.omie.es/inicio

[29] CESPA, http://www.ferrovial.com/es/

[30] Junfeng, L. Institute for Global Environmental Strategies, editor. CDM country guide for China. 1st edition Chinese Renewable Energy Industries Association; 2005.

[31] Urbaser, http://www.urbaser.es/ 